\title{
Fatty acid adaptation in an Antarctic bacterium - changes in primer utilization
}

\author{
David S. Nichols ${ }^{1}$ and Nicholas J. Russell ${ }^{2} \dagger$ \\ Author for correspondence: David S. Nichols. Tel: +61 02 202637. Fax: +61 02202642. \\ e-mail:D.Nichols@agsci.utas.edu.au
}

\begin{abstract}
1 Antarctic CRC and Department of Agricultural Science, University of Tasmania, GPO Box 252C, Hobart, Tasmania 7001, Australia

2 School of Molecular and Medical Biosciences, Department of Biochemistry, University of Wales, PO Box 903, Cardiff CF1 1ST, UK
\end{abstract}

\begin{abstract}
The fatty acid composition and temperature/growth characteristics of a psychrophilic bacterium, strain ACAM 456, isolated from Antarctic sea-ice is reported. The bacterium produced acyl components that may be grouped in three different carbon chain types: even-chain, odd-chain and iso-branched odd-chain. The proportions of these chain types varied according to growth temperature, and were manipulated by growth on L-serine, L-leucine or propionic acid as sole carbon sources. De novo fatty acid synthesis was investigated using sodium $\left[1-{ }^{14} \mathrm{C}\right]$ acetate, $\mathrm{L}-\left[\mathrm{U}-{ }^{14} \mathrm{C}\right]$ leucine and $\mathrm{L}-\left[\mathrm{U}-{ }^{14} \mathrm{C}\right]$ serine as radioactive precursors. Compared with a control culture, resuspension of midexponential phase cells in artificial seawater led to a change in the selection and/or intracellular availability of acyl chain primer molecules. The proportion of radiolabel incorporated into even-chain length components from cells declined, whereas the percentage of radiolabel present in odd-chain length components increased. An increase in incubation temperature augmented this effect, and also elicited a rise in the proportion of label present in branchedchain products. ACAM 456 manipulated the utilization of acyl chain primer molecules as an adaptive response to changes in environmental conditions. In particular, the regulation of odd-chain length fatty acids is described as a novel adaptational response.
\end{abstract}

Keywords: fatty acids, Antarctic bacterium, psychrophile, temperature adaptation

\section{INTRODUCTION}

The adaptation of bacterial fatty acid composition to differing growth conditions has been reported widely, with particular regard to temperature and nutrient variation. The majority of the observed changes in total fatty acid composition have been rationalized in terms of the maintenance of 'optimal' membrane lipid fluidity (Sinensky, 1974; Magnuson et al., 1993; Wieslånder et al., 1995). Another consideration, less often recognized, is the influence of fatty acid composition on the phase behaviour of the lipids, as embodied in the so-called 'lipid-shape hypothesis' (Rilfors et al., 1984) and termed homeophasic adaptation (McElhaney, 1982). Interpretation of data gathered from many different bacterial genera has led to the recognition of three key strategies which may be

†Present address: Microbiology Laboratories, Department of Biological Sciences, Wye College, University of London, Wye, Ashford, Kent TN25 $5 \mathrm{AH}, \mathrm{UK}$.

Abbreviations: FAME, fatty acid methyl ester; FID, flame ionization detector; RASW, resuspension in artificial seawater; ZB, Zobell's broth. employed exclusively or in combination during fatty acid adaptation by a particular bacterium. Russell (1984a) has summarized these adaptive responses as: (i) changes in the degree of individual fatty acid unsaturation, and/or the overall proportion of unsaturated fatty acids, (ii) changes in the chain length of individual fatty acids, and (iii) changes in the proportion of methyl-branched-chain fatty acids, and/or the position of the methyl branch present.

All of the changes in lipid acyl composition, apart from those due to desaturase activity, must involve de novo fatty acid synthesis. Iso- and anteiso-methyl branches cannot be added by methylation of existing fatty acids, but are introduced as part of the primer molecule during the initiation of fatty acid synthesis. It is well known that a major site of fatty acid biosynthetic control resides in the selection of compounds utilized as primer molecules by the fatty acid synthase system. The primer specificity determines the general types of fatty acids able to be synthesized by a bacterium (Fulco, 1983). For bacteria containing high levels of even-chain-length fatty acids, primer specificity is highest for acetyl-CoA or butyrylCoA. In bacteria that synthesize predominantly branched- 
chain fatty acids, specificity is greatest for the branched acyl-CoA primers, derived from branched amino acids (Butterworth \& Bloch, 1970; Kaneda, 1991). The importance of fatty acid primer specificity in the membrane adaptive response has received little attention, particularly in regard to the production of odd-chain-length fatty acids. Synthesis of these components is controlled by utilization of the odd-chain length primer propionylCoA.

The present study investigated de novo fatty acid adaptation with respect to primer availability and utilization in an Antarctic psychrophilic bacterium. We show here that the Antarctic bacterium strain ACAM 456 has the capacity to utilize all three of the fatty acid adaptive strategies outlined above, when grown under differing culture conditions.

\section{METHODS}

Isolation and characteristics of ACAM 456. ACAM 456 (previously designated strain JS6) was isolated from a sea-ice core collected from Prydz Bay, Antarctica (Nichols et al., 1995) and is held within the Australian Collection of Antarctic Microorganisms (ACAM, Antarctic CRC, University of Tasmania, Hobart, Tasmania). The bacterium is an unidentified Gram-negative, non-sporulating pleomorphic rod (Nichols et al., 1995).

Growth rate determination. The effect of temperature on the rate of growth was determined using a temperature gradient incubator (Toyo Kagaku Sangyo, Tokyo, Japan) over the range $-0.3{ }^{\circ} \mathrm{C}$ to $25.0^{\circ} \mathrm{C}$ at approximately one degree Centigrade intervals. The growth medium, Zobell's broth (ZB) (Zobell, 1946), was inoculated with an actively growing culture and growth monitored by percentage transmittance at $540 \mathrm{~nm}$ wavelength. Cultures were shaken via an oscillatory motion of the incubator, through an arc of $60^{\circ}$, at a rate of 60 oscillations $\min ^{-1}$. Growth rates at each temperature were calculated by fitting a modified Gompertz function to the data (McMeekin $e t$ al., 1993). The square root of growth rate data were then fitted to the model of Ratkowsky et al. (1983) using UltraFit software.

Culture conditions for cellular non-radioactive lipid analyses. Triplicate $100 \mathrm{ml}$ cultures of ACAM 456 were grown at $2{ }^{\circ} \mathrm{C}$ and $6^{\circ} \mathrm{C}$ in $\mathrm{ZB}$ to mid-exponential phase in $500 \mathrm{ml}$ flasks without agitation. Three $15 \mathrm{ml}$ cultures from the above growth temperature experiment, incubated at $-0.3{ }^{\circ} \mathrm{C}, 14.9^{\circ} \mathrm{C}$ and $19 \cdot 7^{\circ} \mathrm{C}$, were also utilized. For culture with single carbon sources, the media (James et al., 1990) consisted of $0.5 \%(\mathrm{w} / \mathrm{v}$ ) carbon source and $0.001 \%(\mathrm{w} / \mathrm{v})$ yeast extract in $0.22 \mu \mathrm{m}$ filtered and sterilized natural seawater. Triplicate sole carbon source cultures were incubated at $2{ }^{\circ} \mathrm{C}$ without agitation until sufficient growth was present for harvest. The above cultures were harvested by centrifugation at 7500 r.p.m. for $12 \mathrm{~min}$. Bacterial pellets were collected and freeze-dried before storage at $-70^{\circ} \mathrm{C}$ until lipid analysis. Reproducibility of data was assessed by analysis of the mean and standard deviation values of triplicate $2{ }^{\circ} \mathrm{C}$ samples (Table 1 ).

Culture conditions for radiolabelling. Cultures $(200 \mathrm{ml} \mathrm{ZB}$ in 11 flasks) of ACAM 456 were grown at $15^{\circ} \mathrm{C}$ or $20^{\circ} \mathrm{C}$ without agitation until mid-exponential phase, when $3.7 \mathrm{kBq} \mathrm{ml}^{-1}$ of $\mathrm{L}_{-}$ $\left[\mathrm{U}^{14} \mathrm{C}\right]$ serine or $\mathrm{L}-\left[\mathrm{U}^{-14} \mathrm{C}\right]$ leucine (specific activities $5.3 \mathrm{GBq} \mathrm{mmol}^{-1}$ and $10.4 \mathrm{GBq} \mathrm{mmol}^{-1}$ respectively; ICN Pharmaceuticals) was added to the cultures. At 0.5 and $2.0 \mathrm{~h}$ following addition of radiolabel, $100 \mathrm{ml}$ aliquots of culture were withdrawn for harvest by centrifugation at 7500 r.p.m. for 15 min. Bacterial pellets were extracted immediately for lipid analysis. For resuspension experiments, cultures in ZB were grown as above. When the cultures reached mid-exponential phase, bacterial pellets were collected by centrifugation at 6000 r.p.m. for $10 \mathrm{~min}$. Bacteria were resuspended in an equal volume of sterile artificial seawater containing radiolabel as above or sodium $\left[1-{ }^{14} \mathrm{C}\right]$ acetate (specific activity $2 \cdot 2 \mathrm{GBq} \mathrm{mmol}^{-1}$; Amersham). To certain resuspensions, nonradioactive L-leucine (100 times the concentration of radiolabel) was also added. Resuspended bacteria were incubated at the initial growth temperatures. At 0.5 and $2.0 \mathrm{~h}$ following resuspension, $100 \mathrm{ml}$ aliquots were removed and harvested for immediate extraction as above.

Lipid extraction. Lipids were extracted from bacteria using a modified one-phase $\left(\mathrm{CHCl}_{3} / \mathrm{MeOH} / \mathrm{H}_{2} \mathrm{O}\right)$ Bligh and Dyer extraction (Bligh \& Dyer, 1959; White et al., 1979). A portion of the total-lipid extract recovered from the lower $\mathrm{CHCl}_{3}$ phase was transmethylated by reaction for $1 \mathrm{~h}$ at $80^{\circ} \mathrm{C}$ with dry $\mathrm{MeOH} / \mathrm{CHCl}_{3} / \mathrm{HCl}(10: 1: 1$, by vol., $3 \mathrm{ml})$. After the addition of water $(1 \mathrm{ml})$ the resultant fatty acid methyl esters (FAME) were extracted with $\mathrm{C}_{6} \mathrm{H}_{14} / \mathrm{CHCl}_{3}(4: 1, \mathrm{v} / \mathrm{v} ; 3 \times 2 \mathrm{ml})$. For gas chromatographic (GC) analysis, samples were diluted with $\mathrm{CHCl}_{3}$ containing nonadecanoic acid methyl ester as an internal standard of known concentration.

GC analysis. GC analyses of the FAME were performed with a Hewlett Packard 5890 chromatograph equipped with a $50 \mathrm{~m} \times 0.32 \mathrm{~mm}$ internal diameter cross-linked methyl silicone $(0.17 \mu \mathrm{m}$ film thickness) fused-silica capillary column and flame ionization detector (FID), as described by Nichols et al. (1995). GC-mass spectrometric (GC-MS) analyses of samples were performed on a Hewlett Packard 5890 chromatograph and 5970 mass selective detector, as described by Nichols et al. (1995). The percentage values of fatty acid chain types presented in Figs 2 and 3 represent the sums of individual component percentages as determined from GC analyses.

Radio-GC analyses. FAME samples were analysed using a PyeUnicam chromatograph equipped with a FID connected to a Pannax Reigate series radiogas detector system with a gas-flowproportional counter. A glass column $(1.5 \mathrm{~m} \times 2 \mathrm{~mm}$ internal diameter) packed with $15 \%(\mathrm{w} / \mathrm{w})$ ethylene glycol succinate silicone (EGSS-X) supported on 80-100 mesh Chromosorb W AW (Supelco) was used for FAME separations. Samples were injected at $160^{\circ} \mathrm{C}$. After $28 \mathrm{~min}$, the oven temperature was raised at a rate of 8 degrees Centigrade $\min ^{-1}$ to a final temperature of $200^{\circ} \mathrm{C}$, which was maintained for $15 \mathrm{~min}$. Argon containing $5 \% \mathrm{CO}_{2}(\mathrm{v} / \mathrm{v})$ was used as the carrier gas, and the injector and FID temperatures were maintained at $210^{\circ} \mathrm{C}$ and $230^{\circ} \mathrm{C}$ respectively. FAMEs were identified by comparison of retention times to authentic standards. Mass and radioactivity peaks were quantified by calculation of component peak areas.

\section{RESULTS}

\section{Growth characteristics}

The temperature-growth relationship for strain ACAM 456 in $\mathrm{ZB}$ is shown in Fig. 1. The curve fit had a root mean square error of 0.00205 . The maximum growth temperature $\left(T_{\text {max }}\right)$ was $25.0 \pm 0.2{ }^{\circ} \mathrm{C}(95 \%$ confidence $)$, while the extrapolated theoretical minimum growth temperature $\left(T_{\min }\right)$ was $-26.0 \pm 5.8{ }^{\circ} \mathrm{C}(95 \%$ confidence limit). A relatively broad optimum growth temperature range was observed, with the optimal growth temperature $\left(T_{\text {opt }}\right)$ calculated as $16.5^{\circ} \mathrm{C}$ from the fitted curve, under the experimental conditions employed. 


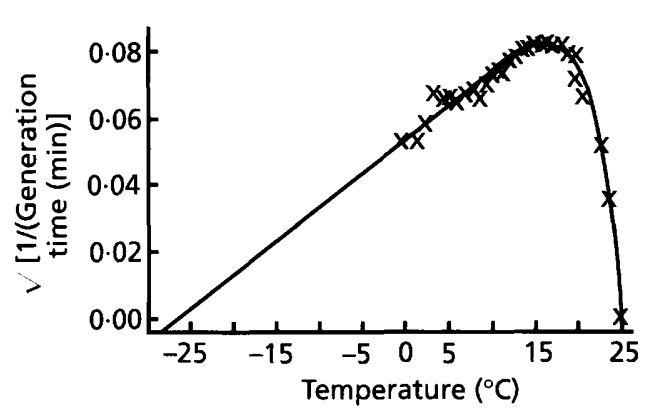

Fig. 1. Plot of $1 / \sqrt{ }$ (growth rate) versus temperature for ACAM 456 grown in $\mathrm{ZB}$. The data shown are from a single representative determination.

Table 1. Fatty acid composition of ACAM 456 grown in ZB at $2{ }^{\circ} \mathrm{C}$

\begin{tabular}{|lr|}
\hline Fatty acid & $\begin{array}{c}\text { Mass percentage composition } \\
\text { (mean } \pm \text { SD, } \boldsymbol{n}=3 \text { ) }\end{array}$ \\
\hline $12: 0$ & $0 \cdot 7 \pm 0 \cdot 0$ \\
i13:0 & $15 \cdot 8 \pm 0 \cdot 3$ \\
$13: 0$ & $1 \cdot 3 \pm 0 \cdot 2$ \\
i14:0 & $0 \cdot 6 \pm 0 \cdot 0$ \\
$14: 1 \omega 7 \mathrm{c}$ & $0 \cdot 8 \pm 0 \cdot 0$ \\
$14: 1 \omega 5 \mathrm{c}$ & $0 \cdot 1 \pm 0 \cdot 0$ \\
$14: 0$ & $4 \cdot 4 \pm 0 \cdot 1$ \\
i15:0 & $8 \cdot 3 \pm 0 \cdot 4$ \\
$15: 0$ & $6 \cdot 7 \pm 0 \cdot 0$ \\
$15: 1 \omega 8 \mathrm{c}$ & $1 \cdot 7 \pm 0 \cdot 0$ \\
$15: 1 \omega 6 \mathrm{c}$ & $1 \cdot 7 \pm 0 \cdot 0$ \\
$16: 0$ & $6 \cdot 4 \pm 0 \cdot 2$ \\
$16: 1 \omega 7 \mathrm{c}$ & $27 \cdot 4 \pm 0 \cdot 5$ \\
$16: 1 \omega 7 \mathrm{t}$ & $0 \cdot 1 \pm 0 \cdot 0$ \\
i17:0 & $0 \cdot 1 \pm 0 \cdot 0$ \\
$17: 0$ & $0 \cdot 5 \pm 0 \cdot 0$ \\
$17: 1 \omega 8 \mathrm{c}$ & $4 \cdot 2 \pm 0 \cdot 1$ \\
$17: 1 \omega 6 \mathrm{c}$ & $0 \cdot 8 \pm 0 \cdot 0$ \\
$18: 0$ & $0 \cdot 1 \pm 0 \cdot 0$ \\
$18: 1 \omega 9 \mathrm{c}$ & $0 \cdot 3 \pm 0 \cdot 0$ \\
$18: 1 \omega 7 \mathrm{c}$ & $1 \cdot 0 \pm 0 \cdot 8$ \\
$18: 4 \omega 3$ & $0 \cdot 3 \pm 0 \cdot 0$ \\
$20: 4 \omega 3$ & $0 \cdot 3 \pm 0 \cdot 0$ \\
$20: 5 \omega 3$ & $16 \cdot 0 \pm 0 \cdot 2$ \\
Other & $0 \cdot 2 \pm 0 \cdot 0$ \\
Total & $100 \cdot 0 \pm 0 \cdot 0$ \\
Sum odd-chain & $16 \cdot 9 \pm 0 \cdot 2$ \\
Sum br-chain & $24 \cdot 8 \pm 0 \cdot 1$ \\
Sum even-chain & $58 \cdot 1 \pm 0 \cdot 1$ \\
\hline & \\
\hline
\end{tabular}

\section{Fatty acid composition}

The fatty acid composition of ACAM 456 grown in $\mathrm{ZB}$ at $2{ }^{\circ} \mathrm{C}$ is shown in Table 1 . Under these growth conditions, the major fatty acids were $16: 1 \omega 7 \mathrm{c}(27 \cdot 4 \pm 0 \cdot 5 \%$ of total fatty acids), $20: 5 \omega 3 \quad(16 \cdot 0 \pm 0 \cdot 2 \%)$ and i13:0

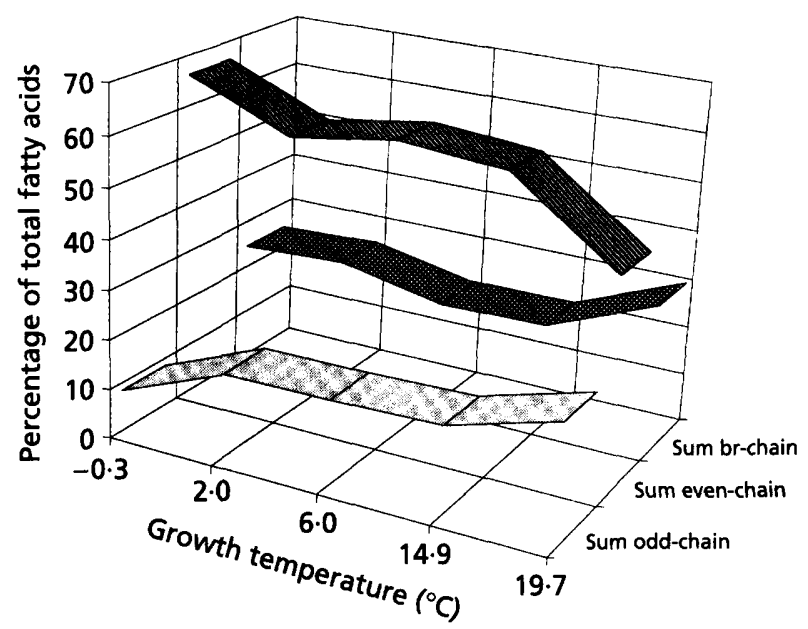

Fig. 2. Percentage of fatty acid chain types at various growth temperatures in ACAM 456 grown in ZB. Data shown for $2.0^{\circ} \mathrm{C}$ and $6.0^{\circ} \mathrm{C}$ are mean values $(n=3)$. Data for $-0.3{ }^{\circ} \mathrm{C}, 14.9{ }^{\circ} \mathrm{C}$ and $19.7^{\circ} \mathrm{C}$ are single determinations.

$(15 \cdot 8 \pm 0 \cdot 3 \%)$. Even-chain acyl components dominated $(58 \cdot 1 \pm 0 \cdot 1 \%)$, with $24 \cdot 8 \pm 0 \cdot 1 \%$ branched-chain components and $16.9 \pm 0.2 \%$ odd-chain fatty acids.

\section{Effect of growth temperature}

The effect of growth temperature between $-0.3{ }^{\circ} \mathrm{C}$ and $19.7^{\circ} \mathrm{C}$ on the percentage of fatty acid chain types from ACAM 456 grown in ZB is shown in Fig. 2. While evenchain components remained the dominant fatty acid type over the growth temperature range, there was a decrease in the percentage of these components as growth temperature increased from $14.9^{\circ} \mathrm{C}$ to $19.7^{\circ} \mathrm{C}$. This was accompanied by an increase in both odd-chain and branched-chain components. At low growth temperature, this pattern was reversed. The percentage of even-chain components increased, as the level of odd-chain fatty acids decreased.

\section{Effect of sole carbon source}

The total percentages of fatty acid chain types from cultures grown at $2{ }^{\circ} \mathrm{C}$ on L-leucine, L-serine or propionic acid as the sole carbon source are shown in Fig. 3. Growth on L-serine resulted in a distribution of fatty acid chain types similar to that observed for growth in a complex medium (ZB), apart from a lower proportion of branchedchain components (17\% compared with $25 \%$ ). In comparison to growth in $\mathrm{ZB}$, growth on L-leucine led to an increase in the proportion of branched-chain components from $25 \%$ to $36 \%$, whereas even-chain components decreased by $4 \%$ and odd-chain components by $8 \%$. The greatest effect on fatty acid composition occurred when the growth substrate was propionic acid. The sum of odd-chain components increased from $17 \%(\mathrm{ZB})$ to $55 \%$ (propionic acid), accompanied by decreases in the proportion of both even-chain (58\% to $30 \%$ ) and branchedchain $(25 \%$ to $12 \%)$ components. 


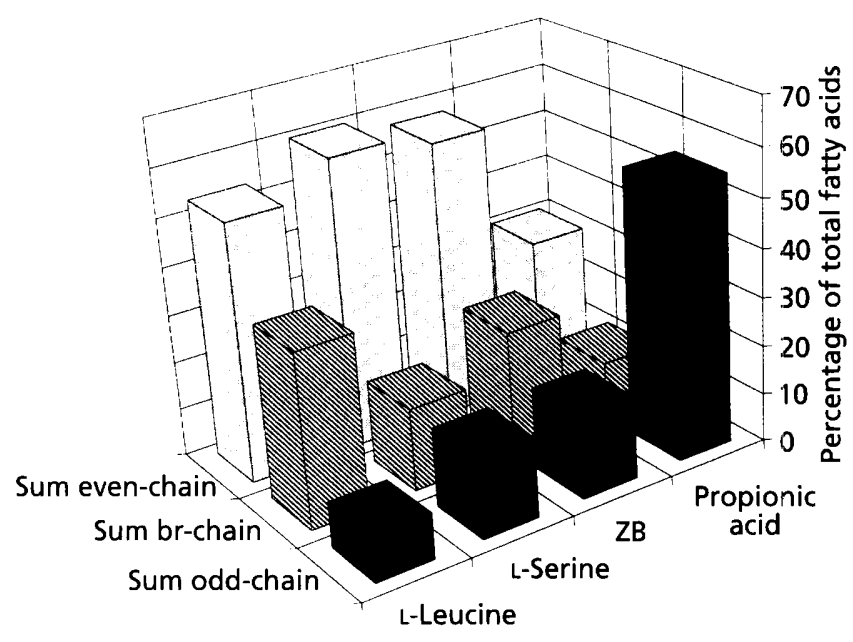

Fig. 3. Percentage of fatty acid chain types in ACAM 456 grown with different sole carbon sources at $2^{\circ} \mathrm{C}$. Data shown are mean values $(n=3)$.

\section{Radiolabelling of fatty acids with $\mathrm{L}-\left[\mathrm{U}-{ }^{14} \mathrm{C}\right]$ serine}

The percentage distribution of radioactivity in fatty acids during growth in $\mathrm{ZB}$ with $\mathrm{L}-\left[\mathrm{U}_{-}{ }^{14} \mathrm{C}\right]$ serine $\left(\left[{ }^{14} \mathrm{C}\right] \mathrm{Ser}\right)$ at $15{ }^{\circ} \mathrm{C}$ is given in Table 2 . Fatty acid radiolabel percentage compositions for cells resuspended in artificial seawater (RASW) and labelled with $\left[{ }^{14} \mathrm{C}\right]$ Ser are shown in Table 3. Cells labelled in $\mathrm{ZB}$ at $15^{\circ} \mathrm{C}$ accumulated the majority of radioactivity in 16:0,16:1 and 20:503 (Table 2). These fatty acids were also the major mass percentage components. The similar percentage distribution of radiolabel and mass percentage values (data not shown) implies that incorporation of radiolabel had reached an equilibrium position before $0.5 \mathrm{~h}$ of incubation with label. The mass percentage composition of RASW cultures at $15{ }^{\circ} \mathrm{C}$ (data not shown) was also similar to that of cultures grown in $\mathrm{ZB}$, suggesting no major disruption to bacterial metabolism had occurred during centrifugation and resuspension.

In the $15^{\circ} \mathrm{C}$ RASW cultures, there was a marked increase in the percentage of radiolabel present in the odd-chain fatty acid series compared to the ZB culture $(10-11 \% \mathrm{ZB}$; $28-33 \%$ RASW). This was due chiefly to greater incorporation of radioactivity in $15: 0$ and $17: 1$, which increased from $5 \%$ and $2 \%$ respectively ( $\mathrm{ZB}$ culture) to $17 \%$ and $6 \%$ (RASW culture). Concurrently, the percentage of radiolabel present in the even-chain fatty acid series decreased, particularly for $16: 1$ (33\% ZA ; 19-22\% RASW). The proportion of radiolabel incorporated into branched-chain components remained relatively constant.

An increase in the growth temperature of RASW cultures from $15^{\circ} \mathrm{C}$ to $20^{\circ} \mathrm{C}$ led to an augmentation of the above effect (Tables 2 and 3). Levels of radiolabel in odd-chain components reached their highest value $(38-40 \%)$ while the percentage of radioactivity present in even-chain components decreased to $44-49 \%$ (compared to $62-69 \%$ RASW, $15{ }^{\circ} \mathrm{C}$ and $\left.83-85 \% \mathrm{ZB}, 15^{\circ} \mathrm{C}\right)$. However, incubation of RASW cultures at $20^{\circ} \mathrm{C}$ also led to an increase
Table 2. Percentage distribution of radioactivity from L$\left[\mathrm{U}-{ }^{14} \mathrm{C}\right]$ serine or $\mathrm{L}-\left[\mathrm{U}-{ }^{14} \mathrm{C}\right]$ leucine in fatty acids of ACAM 456 grown at $15^{\circ} \mathrm{C}$ in $\mathrm{ZB}$

The results are from single determinations.

\begin{tabular}{|c|c|c|c|}
\hline \multirow[t]{2}{*}{ Fatty acid } & \multicolumn{3}{|c|}{$\begin{array}{l}\text { Radioactive percentage } \\
\text { composition* }\end{array}$} \\
\hline & $\begin{array}{c}0.5 \\
\text { L-Ser }\end{array}$ & $\begin{array}{c}2 \cdot 0 \\
\text { L-Ser }\end{array}$ & $\begin{array}{c}2 \cdot 0 \\
\text { L-Leu }\end{array}$ \\
\hline $12: 0$ & $0 \cdot 1$ & $0 \cdot 2$ & $\mathrm{tr}$ \\
\hline $\mathrm{i} 13: 0$ & $1 \cdot 4$ & $2 \cdot 3$ & $42 \cdot 2$ \\
\hline $13: 0$ & $0 \cdot 4$ & $0 \cdot 6$ & $1 \cdot 3$ \\
\hline i14:0 & $0 \cdot 1$ & $0 \cdot 3$ & - \\
\hline $14: 0$ & $7 \cdot 6$ & $8 \cdot 7$ & $4 \cdot 2$ \\
\hline i15:0‡ & $2 \cdot 5$ & $2 \cdot 9$ & $9 \cdot 7$ \\
\hline $15: 0$ & $5 \cdot 6$ & $5 \cdot 2$ & $2 \cdot 8$ \\
\hline $15: 1 \S$ & $1 \cdot 2$ & $2 \cdot 5$ & $2 \cdot 7$ \\
\hline $16: 0$ & $15 \cdot 8$ & $12 \cdot 5$ & $5 \cdot 5$ \\
\hline $16: 1 \S$ & $33 \cdot 4$ & $33 \cdot 8$ & $16 \cdot 1$ \\
\hline $17: 0$ & $0 \cdot 5$ & $0 \cdot 7$ & $\operatorname{tr}$ \\
\hline $17: 1 \S$ & $2 \cdot 1$ & $1 \cdot 8$ & $\mathrm{tr}$ \\
\hline $18: 0$ & $\operatorname{tr}$ & - & - \\
\hline $18: 15$ & $1 \cdot 1$ & $0 \cdot 9$ & $3 \cdot 0$ \\
\hline $18: 2 \|$ & - & - & - \\
\hline $18: 3 \|$ & $0 \cdot 3$ & $0 \cdot 3$ & $0 \cdot 8$ \\
\hline $18: 4 \omega 3$ & $0 \cdot 5$ & $\operatorname{tr}$ & - \\
\hline $20: 3 \|$ & $0 \cdot 4$ & $0 \cdot 3$ & $\operatorname{tr}$ \\
\hline $20: 4 \omega 3$ & $1 \cdot 1$ & $0 \cdot 7$ & $\operatorname{tr}$ \\
\hline $20: 5 \omega 3$ & $25 \cdot 4$ & $26 \cdot 1$ & $10 \cdot 2$ \\
\hline Other & 0.5 & $0 \cdot 4$ & $1 \cdot 6$ \\
\hline Total & $100 \cdot 0$ & $100 \cdot 0$ & $100 \cdot 0$ \\
\hline Sum odd-chain & $9 \cdot 8$ & $10 \cdot 7$ & 6.8 \\
\hline Sum br-chain & $4 \cdot 0$ & $5 \cdot 5$ & $51 \cdot 8$ \\
\hline Sum even-chain & $85 \cdot 7$ & $83 \cdot 4$ & $39 \cdot 8$ \\
\hline
\end{tabular}

*-, Below detection; $\mathrm{tr},<0.1 \%$.

$\dagger$ Time after addition of label.

$\ddagger$ Plus $<1 \% 14: 1$.

§Unresolved multiple isomers: see Table 1.

|| Double bond positions not determined.

in radioactivity incorporated into branched-chain components $\left(10-15 \%\right.$ at $20{ }^{\circ} \mathrm{C}$ compared with $2-5 \%$ at $\left.15{ }^{\circ} \mathrm{C}\right)$. The majority of this effect was due to i13:0 $(1-2 \%$ at $15^{\circ} \mathrm{C}$ versus $4-7 \%$ at $20^{\circ} \mathrm{C}$ ). The addition of excess non-radioactive L-leucine had little effect on the overall percentage distribution of radioactivity in fatty acids of $15^{\circ} \mathrm{C}$ RASW cultures (Table 3 ). However, there was an increase in the percentage of radiolabel incorporated into $20: 5 \omega 3$ (about $4-8 \%$ ).

\section{Radiolabelling of fatty acids with sodium [1- $\left.{ }^{14} \mathrm{C}\right]$ acetate}

Fatty acid radiolabel percentage compositions for RASW cultures labelled with sodium $\left[1-{ }^{14} \mathrm{C}\right]$ acetate $\left(\left[{ }^{14} \mathrm{C}\right]\right.$ acetate $)$ 
Table 3. Incorporation of $\mathrm{L}-\left[\mathrm{U}-{ }^{14} \mathrm{C}\right]$ serine in ACAM 456 resuspended in artificial seawater at 15 or $20^{\circ} \mathrm{C}$ with or without the presence of non-radioactive L-leucine

The results are from single determinations.

\begin{tabular}{|c|c|c|c|c|c|c|}
\hline \multirow[b]{2}{*}{$\begin{array}{r}\text { Time }(h) \dagger \ldots \\
\text { Temp. }\left({ }^{\circ} \mathrm{C}\right) . . \\
\text { L-Leucine... }\end{array}$} & \multicolumn{6}{|c|}{ Radioactive percentage composition* } \\
\hline & $\begin{array}{c}0.5 \\
15 \\
(+)\end{array}$ & $\begin{array}{c}2 \cdot 0 \\
15 \\
(+)\end{array}$ & $\begin{array}{c}0.5 \\
15 \\
(-)\end{array}$ & $\begin{array}{c}2 \cdot 0 \\
15 \\
(-)\end{array}$ & $\begin{array}{c}0.5 \\
20 \\
(+)\end{array}$ & $\begin{array}{c}2 \cdot 0 \\
20 \\
(+)\end{array}$ \\
\hline $12: 0$ & $\operatorname{tr}$ & $0 \cdot 2$ & $0 \cdot 1$ & - & $0 \cdot 2$ & $0 \cdot 2$ \\
\hline i13:0 & $1 \cdot 2$ & 0.5 & 0.8 & 1.5 & $7 \cdot 2$ & $4 \cdot 2$ \\
\hline $13: 0$ & $0 \cdot 8$ & $0 \cdot 4$ & $0 \cdot 8$ & $2 \cdot 3$ & $2 \cdot 6$ & $2 \cdot 3$ \\
\hline i14:0 & $0 \cdot 4$ & - & $0 \cdot 2$ & $0 \cdot 2$ & $\operatorname{tr}$ & 0.4 \\
\hline $14: 0$ & $3 \cdot 0$ & $2 \cdot 2$ & $2 \cdot 5$ & $4 \cdot 0$ & $4 \cdot 9$ & $7 \cdot 5$ \\
\hline $\mathrm{i} 15: 0 \ddagger$ & 3.7 & 1.9 & $1 \cdot 5$ & $2 \cdot 7$ & $8 \cdot 2$ & $5 \cdot 7$ \\
\hline $15: 0$ & $17 \cdot 0$ & $17 \cdot 1$ & $19 \cdot 7$ & $20 \cdot 6$ & $25 \cdot 4$ & $25 \cdot 7$ \\
\hline $15: 1 \S$ & $4 \cdot 4$ & $2 \cdot 4$ & $2 \cdot 9$ & $3 \cdot 8$ & 4.9 & $4 \cdot 5$ \\
\hline $16: 0$ & $10 \cdot 2$ & $9 \cdot 9$ & 8.9 & $8 \cdot 6$ & $11 \cdot 8$ & $12 \cdot 1$ \\
\hline $16: 15$ & $19 \cdot 0$ & $18 \cdot 8$ & $21 \cdot 8$ & $19 \cdot 8$ & $21 \cdot 8$ & $20 \cdot 8$ \\
\hline $17: 0^{\circ}$ & $0 \cdot 9$ & $1 \cdot 4$ & $2 \cdot 4$ & $1 \cdot 3$ & $1 \cdot 6$ & $2 \cdot 3$ \\
\hline $17: 15$ & $5 \cdot 7$ & $6 \cdot 7$ & 6.5 & $5 \cdot 2$ & $4 \cdot 0$ & $5 \cdot 3$ \\
\hline $18: 0$ & - & $0 \cdot 3$ & $\operatorname{tr}$ & - & $\operatorname{tr}$ & $\operatorname{tr}$ \\
\hline $18: 1 \S$ & $1 \cdot 9$ & $2 \cdot 0$ & $1 \cdot 7$ & $1 \cdot 2$ & $1 \cdot 2$ & $1 \cdot 6$ \\
\hline $18: 2 \|$ & - & - & $\operatorname{tr}$ & - & - & - \\
\hline $18: 3 \|$ & $0 \cdot 4$ & 0.4 & $0 \cdot 3$ & $0 \cdot 4$ & $\mathrm{tr}$ & $0 \cdot 3$ \\
\hline $18: 4 \omega 3$ & $0 \cdot 2$ & - & $0 \cdot 2$ & 0.9 & 0.9 & $0 \cdot 3$ \\
\hline $20: 3 \|$ & $0 \cdot 2$ & $0 \cdot 6$ & $0 \cdot 7$ & $0 \cdot 6$ & $1 \cdot 1$ & $1 \cdot 6$ \\
\hline $20: 4 \omega 3$ & $0 \cdot 2$ & $0 \cdot 7$ & $2 \cdot 4$ & 0.6 & $1 \cdot 1$ & $1 \cdot 2$ \\
\hline $20: 5 \omega 3$ & $30 \cdot 6$ & $33 \cdot 8$ & $25 \cdot 6$ & $25 \cdot 9$ & $1 \cdot 7$ & $2 \cdot 9$ \\
\hline Other & $0 \cdot 2$ & 0.7 & $0 \cdot 8$ & $0 \cdot 6$ & $1 \cdot 6$ & $1 \cdot 0$ \\
\hline Total & $100 \cdot 0$ & $100 \cdot 0$ & $100 \cdot 0$ & $100 \cdot 0$ & $100 \cdot 0$ & $100 \cdot 0$ \\
\hline Sum odd-chain & $28 \cdot 8$ & $28 \cdot 0$ & $32 \cdot 3$ & $33 \cdot 2$ & $38 \cdot 4$ & $40 \cdot 1$ \\
\hline Sum br-chain & $5 \cdot 3$ & $2 \cdot 5$ & $2 \cdot 5$ & $4 \cdot 4$ & $15 \cdot 4$ & $10 \cdot 3$ \\
\hline Sum even-chain & $65 \cdot 8$ & $68 \cdot 8$ & $64 \cdot 3$ & $61 \cdot 8$ & $44 \cdot 6$ & $48 \cdot 5$ \\
\hline
\end{tabular}

*.., Below detection; tr, $<0.1 \%$.

† Label time from culture resuspension.

$\ddagger$ Plus $<1 \% 14: 1$.

§, || See Table 2.

at $15^{\circ} \mathrm{C}$ or $20^{\circ} \mathrm{C}$ in the presence of non-radioactive $\mathrm{L}$ leucine are shown in Table 4 . In general, the radiolabel percentage distribution pattern mirrored that observed for the $\left[{ }^{14} \mathrm{C}\right]$ Ser experiments with non-radioactive $\mathrm{L}$ leucine added. However, several differences were apparent. The $15^{\circ} \mathrm{C}$ culture exhibited a higher percentage of label incorporation in 15:0 than was observed with $\left[{ }^{14} \mathrm{C}\right] \operatorname{Ser}(21-24 \%$ compared to $17 \%)$. The percentage of radioactivity present in $16: 1$ also increased with time in both the $15^{\circ} \mathrm{C}$ and $20^{\circ} \mathrm{C}$ cultures, but remained lower than that observed in the cultures labelled with $\left[{ }^{14} \mathrm{C}\right] \mathrm{Ser}$ $\left(12-16 \%\right.$ versus $19 \%$ at $15{ }^{\circ} \mathrm{C} ; 12-17 \%$ compared with $21-22 \%$ at $20^{\circ} \mathrm{C}$ ). There was also a smaller proportion $(8-10 \%)$ of label incorporated in $20: 5 \omega 3$ compared to labelling with $\left[{ }^{14} \mathrm{C}\right] \mathrm{Ser}$ at $15^{\circ} \mathrm{C}$. This was accompanied by a smaller (4-10\%) mass percentage of $20: 5 \omega 3$. In $20^{\circ} \mathrm{C}$ cultures, the percentage of radioactivity present in $113: 0$ and $i 15: 0$ at $0.5 \mathrm{~h}$ was greater than observed at $15^{\circ} \mathrm{C}$, mirroring the pattern present in cultures labelled with $\left[{ }^{14} \mathrm{C}\right]$ Ser. By $2 \mathrm{~h}$, these proportions had decreased, whereas the percentage of label in 15:0 increased markedly.

\section{Radiolabelling of fatty acids with $\mathrm{L}-\left[\mathrm{U}-{ }^{14} \mathrm{C}\right]$ leucine}

The fatty acid radiolabel percentage composition for ACAM 456 grown with $\mathrm{L}-\left[\mathrm{U}_{-}{ }^{14} \mathrm{C}\right]$ leucine $\left(\left[{ }^{14} \mathrm{C}\right] \mathrm{Leu}\right)$ at $15^{\circ} \mathrm{C}$ in $\mathrm{ZB}$ is shown in Table 2 . The mass percentage composition of fatty acid components after $2 \mathrm{~h}$ was similar to that of the $\left[{ }^{14} \mathrm{C}\right]$ Ser-labelled $\mathrm{ZB}$ and RASW cultures grown at the same temperature (data not shown). However, there was a marked concentration of label in i13:0 (42\% of total radioactivity) and to a lesser extent i15:0 (10\%). Label incorporation in all even-chain components was greatly reduced, but still apparent. 
Table 4. Incorporation of sodium $\left[1-{ }^{14} \mathrm{C}\right]$ acetate in ACAM 456 resuspended in artificial seawater at 15 or $20^{\circ} \mathrm{C}$ with the presence of non-radioactive L-leucine

The results are from single determinations.

\begin{tabular}{|c|c|c|c|c|}
\hline Fatty acid & \multicolumn{4}{|c|}{$\begin{array}{l}\text { Radioactive percentage } \\
\text { composition* }\end{array}$} \\
\hline Time (h)†... & 0.5 & $2 \cdot 0$ & 0.5 & $2 \cdot 0$ \\
\hline Temp. $\left({ }^{\circ} \mathrm{C}\right) \ldots$ & 15 & 15 & 20 & 20 \\
\hline $12: 0$ & - & 0.4 & $0 \cdot 2$ & $\mathrm{tr}$ \\
\hline i13:0 & $0 \cdot 4$ & $5 \cdot 5$ & $11 \cdot 0$ & $0 \cdot 2$ \\
\hline $13: 0$ & 0.5 & $1 \cdot 5$ & $1 \cdot 4$ & $0 \cdot 2$ \\
\hline i14:0 & $0 \cdot 4$ & $0 \cdot 3$ & 0.6 & $\operatorname{tr}$ \\
\hline $14: 0$ & $2 \cdot 0$ & $5 \cdot 0$ & $5 \cdot 4$ & $3 \cdot 0$ \\
\hline i15:0† & $4 \cdot 0$ & $3 \cdot 4$ & $18 \cdot 8$ & $7 \cdot 4$ \\
\hline $15: 0$ & $23 \cdot 6$ & $21 \cdot 2$ & $25 \cdot 8$ & $37 \cdot 5$ \\
\hline $15: 1 \S$ & $1 \cdot 7$ & $0 \cdot 8$ & $3 \cdot 0$ & $2 \cdot 7$ \\
\hline $16: 0$ & $10 \cdot 3$ & $15 \cdot 2$ & $11 \cdot 0$ & $15 \cdot 4$ \\
\hline $16: 15$ & $11 \cdot 9$ & $16 \cdot 3$ & $11 \cdot 7$ & $16 \cdot 6$ \\
\hline $17: 0$ & $4 \cdot 2$ & $1 \cdot 7$ & $2 \cdot 5$ & $4 \cdot 2$ \\
\hline $17: 1 \int$ & $7 \cdot 0$ & $2 \cdot 6$ & $4 \cdot 1$ & $7 \cdot 6$ \\
\hline $18: 0$ & $\operatorname{tr}$ & $0 \cdot 2$ & $\operatorname{tr}$ & $\operatorname{tr}$ \\
\hline $18: 1 \S$ & 2.9 & 1.9 & $\operatorname{tr}$ & 1.5 \\
\hline $18: 2 \|$ & 0.5 & $\operatorname{tr}$ & - & $\operatorname{tr}$ \\
\hline $18: 3 \|$ & $1 \cdot 7$ & $0 \cdot 2$ & $0 \cdot 3$ & $\operatorname{tr}$ \\
\hline $18: 4 \omega 3$ & $1 \cdot 0$ & $0 \cdot 3$ & 0.6 & $0 \cdot 2$ \\
\hline $20: 3 \|$ & $1 \cdot 1$ & $0 \cdot 3$ & $0 \cdot 6$ & $0 \cdot 4$ \\
\hline $20: 4 \omega 3$ & $0 \cdot 8$ & $0 \cdot 8$ & $\operatorname{tr}$ & $0 \cdot 3$ \\
\hline $20: 5 \omega 3$ & $24 \cdot 8$ & $22 \cdot 1$ & $3 \cdot 0$ & $2 \cdot 6$ \\
\hline Other & $1 \cdot 0$ & $0 \cdot 3$ & $\mathrm{tr}$ & D. 2 \\
\hline Total: & $100 \cdot 0$ & $100 \cdot 0$ & $100 \cdot 0$ & $100 \cdot 0$ \\
\hline Sum odd-chain & $37 \cdot 0$ & $27 \cdot 8$ & $36 \cdot 8$ & $52 \cdot 2$ \\
\hline Sum br-chain & $4 \cdot 9$ & $9 \cdot 2$ & $30 \cdot 4$ & $7 \cdot 7$ \\
\hline Sum even-chain & $57 \cdot 1$ & $62 \cdot 8$ & $32 \cdot 8$ & $39 \cdot 9$ \\
\hline
\end{tabular}

*-, Below detection; tr, $<0 \cdot 1 \%$.

$\dagger$ Label time from culture resuspension.

$\ddagger$ Plus $<1 \% 14: 1$.

f, $\|$ See Table 2.

\section{DISCUSSION}

The growth temperature characteristics of ACAM 456 (Fig. 1) clearly define this bacterium as being psychrophilic. Whereas the measured $T_{\text {opt }}$ and $T_{\max }$ of an organism may vary depending on experimental conditions, $T_{\min }$ has been shown to remain constant, and may be regarded as an intrinsic property of a bacterium (McMeekin et al., 1987). Ratkowsky et al. (1982) noted the use of $T_{\min }$ values for the characterization of bacteria as psychrophilic, psychrotolerant, mesophilic or thermophilic. A $T_{\min }$ range of $-25^{\circ} \mathrm{C}$ to $-14^{\circ} \mathrm{C}$ was suggested as denoting psychrophilic character. The $T_{\min }$ of AC.AM $456\left(-26.0 \pm 5.8{ }^{\circ} \mathrm{C}\right)$ falls toward the lower end of this range, and is similar to that of the extreme psychrophile reported by Harder \& Veldkamp (1971). This implies that ACAM 456 is highly adapted to psychrophilic growth.
The fatty acid synthase of ACAM 456 is a versatile system, as it produces acyl components of three different chain types, and therefore presumably utilizes at least three different primers: acetyl-CoA/butyryl-CoA, propionylCoA and 3-methylbutyryl-CoA. While even-chain fatty acids account for the major percentage of components under all culture conditions employed, odd-chain $\left(C_{15}\right.$ and $\mathrm{C}_{17}$ ) and iso-branched odd-chain components (i13:0 and i15:0) represent significant proportions of the fatty acids (Table 1, Figs 2 and 3). The results depicted in Fig. 2 indicate that there was a shift in the relative proportions of the three different acyl chain classes in response to growth temperature at the sub-optimal and supra-optimal extremes of growth. This implies that there is a change in the utilization of acyl chain primers. Many bacteria manipulate fatty acid chain length within a homologous chain type series (e.g. $C_{16 / 18}$ or $C_{15 / 17}$ ) (Russell, 1984b). However, manipulation of the ratio of even- and oddchain length fatty acids by this bacterium is a novel finding.

De novo manipulation of acyl chain primers was investigated using $\left[{ }^{14} \mathrm{C}\right] \mathrm{Ser},\left[{ }^{14} \mathrm{C}\right]$ acetate and $\left[{ }^{14} \mathrm{C}\right] \mathrm{Leu}$. Labelling of cells that had been resuspended in artificial seawater at $15^{\circ} \mathrm{C}$ with either $\left[{ }^{14} \mathrm{C}\right]$ acetate or $\left[{ }^{14} \mathrm{C}\right]$ Ser demonstrated a marked increase in the de novo synthesis of odd-chain fatty acids, particularly 15:0, and to a lesser extent 17:1 (Tables 3 and 4). Concurrently, the proportion of radioactivity incorporated in even-chain components $(16: 0,16: 1$ and $20: 5 \omega 3)$ decreased. These results indicate a de novo shift in primer selection/utilization from even- to odd-chain molecules. As the radiolabel was the only exogenous carbon source available in each resuspension labelling experiment, the shift in chain length synthesis observed may only have occurred from a change in primer selection specificity by the fatty acid synthase, or a change in the mobilization or utilization of intracellular acetyl-/butyrylCoA and propionyl-CoA pools. A further implication is that in the cases of both $\left[{ }^{14} \mathrm{C}\right]$ Ser and $\left[{ }^{14} \mathrm{C}\right]$ acetate labelling, these compounds were either converted biosynthetically to propionyl-CoA primer, or led to an increase in propionyl-CoA utilization from an intracellular pool. However, labelling with $\left[{ }^{14} \mathrm{C}\right]$ acetate did lead to a higher percentage of radiolabel accumulation in 15:0 and less incorporation into $16: 1$ and $20: 5 \omega 3$ than observed for $\left[{ }^{14} \mathrm{C}\right]$ Ser under identical RASW conditions, suggesting that $\left[1-{ }^{14} \mathrm{C}\right]$ acetate (i) was acting as a poorer even-chain primer than $\left[{ }^{14} \mathrm{C}\right] \mathrm{Ser}$; (ii) stimulated the utilization of propionyl primer to a greater extent; and/or (iii) may have acted as a more successful propionyl precursor.

The added stress of supra-optimal growth temperature $\left(20^{\circ} \mathrm{C}\right)$ combined with that of resuspension of cells in artificial seawater led to a greater proportion of label accumulation in 15:0. In cultures labelled with both $\left[{ }^{14} \mathrm{C}\right]$ Ser and $\left[{ }^{14} \mathrm{C}\right]$ acetate, the level of radioactive incorporation also increased in $113: 0$ and $115: 0$. After $0.5 \mathrm{~h}$, levels of $\left[{ }^{14} \mathrm{C}\right]$ acetate label in the branched-chain components began to fall, while accumulation in 15:0 continued to rise. The addition of supra-optimal temperature stress therefore elicited a polyphasic response, with a broader change in primer utilization, including 
increased utilization of the branched-chain primer 3methylbutyryl-CoA as well as propionyl-CoA. This effect is supported by growth of ACAM 456 at differing culture temperatures in ZB (Fig. 2).

However, as the radiolabels $\left(\left[{ }^{14} \mathrm{C}\right] \mathrm{Ser}\right.$ and $\left[{ }^{14} \mathrm{C}\right]$ acetate respectively) were the sole exogenous carbon sources available to cells during resuspension, the question of a potential exogenous primer effect must also be addressed. The question of primer availability, and its effect on fatty acid composition, was investigated by Ingram et al. (1977). These workers reported that although both Bacillus subtilus and Escherichia coli do not 'naturally' synthesize odd-chain fatty acids, exogenous propionate could be incorporated in vivo as a fatty acid chain primer, leading to the synthesis of 'unnatural' $C_{15}$ and $C_{17}$ fatty acids. A further in vivo study also demonstrated the effects of exogenous primer availability and competition (White, 1984). When grown in a glycine medium free of normal fatty acids, Arthrobacter globiformis produced a15:0 and a16:0 as major fatty acids. With the addition of $0.1 \mathrm{mg}$ [U${ }^{2} \mathrm{H}_{15}$ ]octanoic acid $\mathrm{ml}^{-1}$ to the medium, the total percentage of $\mathrm{n}-\mathrm{C}_{14}$ and $\mathrm{n}-\mathrm{C}_{16}$ fatty acids increased tenfold. The pattern of deuterium labelling within these components indicated that the deuterated octanoic acid had been $\beta$-oxidized to $\left[\mathrm{U}_{-}{ }^{2} \mathrm{H}_{7}\right.$ ] butyryl-CoA, which had then successfully competed with the branched-chain primer for fatty acid synthesis. Similar results using non-radioactive compounds were obtained with B. subtilis (Kaneda, 1963).

The potential role of competition between exogenous primer availability for ACAM 456 was investigated by the addition of excess non-radioactive L-leucine to RASW cultures labelled with $\left[{ }^{14} \mathrm{C}\right]$ Ser at $15^{\circ} \mathrm{C}$ or $20^{\circ} \mathrm{C}$. There was no significant change in the overall pattern of label distribution with the addition of non-radioactive $\mathrm{L}^{-}$ leucine. Presumably, both amino acids were successfully transported independently inside the cell (Kaneda, 1963). Again, this implies that the selection or internal regulation of primer availability was regulated tightly in response to environmental conditions, and that there was little competition between potential primer molecules, based on exogenous availability, in this bacterium. However, there did appear to be a higher level of label incorporation in 20:5 $\omega 3$ when non-radioactive L-leucine was present in resuspensions. This may have been due to a greater extent of $\left[{ }^{14} \mathrm{C}\right] \mathrm{Ser}$ transport into cells under these conditions, via a L-leucine-induced transport mechanism (Hama et al., 1988 ), or to a more subtle effect of leucine metabolism (Calvo \& Matthews, 1994).

Further evidence of the primer regulation exhibited by ACAM 456 was gained from growth on different sole carbon sources (Fig. 3). Growth on L-leucine did result in an increase in the percentage of iso-branched-chain components, while growth on propionic acid also increased the proportion of odd-chain fatty acids to a considerable extent. However, the fact that branchedchain fatty acids were still synthesized when ACAM 456 was grown on sole carbon sources such as L-serine or propionic acid indicates that this bacterium is capable of manipulating intracellular primer availability when these compounds are not available exogenously. Interestingly, growth on L-serine yielded a fatty acid composition very similar to that observed from growth in complex media, suggesting that this compound may represent a 'central' metabolite.

Labelling of ACAM 456 with $\left[{ }^{14} \mathrm{C}\right]$ Leu in ZB (Table 2) clearly indicated that exogenous L-leucine is utilized as a branched-chain primer source, and that the major branched fatty acid product is i13:0. However, radioactivity was also evident in both straight-chain fatty acid series (odd- and even-chain), particularly 16:1, implying that in complex media too, a certain proportion of $\left[{ }^{14} \mathrm{C}\right]$ Leu is metabolized to straight-chain primer and/or elongation units. This supports the general picture of primer interchange that we propose.

ACAM 456 exhibits the de novo synthesis of a wide range of fatty acids that may be grouped into three main chain types: even-chain, odd-chain and iso-branched odd-chain. Incorporation of ${ }^{14} \mathrm{C}$-radiolabel into fatty acids of ACAM 456 demonstrated a change in the pattern of de novo fatty acid synthesis in response to stress conditions such as resuspension in artificial seawater and supra-optimal growth temperature. These results point to a change in the utilization of fatty acid primer molecules by the fatty acid synthase system as an adaptive response to environmental stress. This adaptive response implies a manipulation of fatty acid synthesis at an early, but as yet undetermined, stage in the biosynthetic pathway. In particular, the de novo regulation of odd-chain-length fatty acids is described as a novel adaptational response in this bacterium.

\section{ACKNOWLEDGEMENTS}

This research was supported by the Antarctic Science Advisory Committee and a British Council Postgraduate Bursary awarded to D.S.N., who thanks members of Lab 315, Department of Biochemistry, UWCC, for all their help and encouragement. Dr June Olley and Dr Peter Nichols are thanked for valuable comments, and Professor Tom McMeekin is thanked for ongoing support. CSIRO Division of Oceanography is acknowledged for access to instrumentation.

\section{REFERENCES}

Bligh, E. G. \& Dyer, W. J. (1959). A rapid method for total lipid extraction and purification. Can J Biochem Pbysiol 37, 911-917.

Butterworth, P. H. W. \& Bloch, K. (1970). Comparative aspects of fatty acid synthesis in Bacillus subtilis and Escherichia coli. Eur J Biochem 12, 496-501.

Calvo, J. M. \& Matthews, R. G. (1994). The leucine-responsive regulatory protein, a global regulator of metabolism in Escherichia coli. Microbiol Rev 58, 466-490.

Fulco, A. J. (1983). Fatty acidas of bacteria. Prog Lipid Res 22, 133-160.

Hama, H., Shimamoto, T., Tsuda, M. \& Tsuchiya, T. (1988). Characterisation of a novel L-serine transport system in Escherichia coli. J Bacteriol 170, 2236-2239.

Harder, W. \& Veldkamp, H. (1971). Competition of marine psychrophilic bacteria at low temperatures. Antonie Leewwenboek 37, $51-63$. 
Ingram, L. O., Chevalier, L. S., Gabbay, E. J., Ley, K. D. \& Winters, K. (1977). Propionate-induced synthesis of odd-chain-length fatty acids by E. coli. J Bacteriol 131, 1023-1025.

James, S. R., Dobson, S. J., Franzmann, P. D. \& McMeekin, T. A. (1990). Halomonas meridiana, a new species of extremely halotolerant bacteria isolated from Antarctic saline lakes. Syst Appl Microbiol 13, 270-278.

Kaneda, T. (1963). Biosynthesis of branched chain fatty acids. J Biol Chem 238, 1229-1235.

Kaneda, T. (1991). Iso- and anteiso-fatty acids in bacteria: biosynthesis, function and taxonomic significance. Microbiol Rev 55, 288-302.

Magnuson, K., Jackowski, S., Rock, C. O. \& Cronan, J. E., Jr (1993). Regulation of fatty acid biosynthesis in Eschericbia coli. Microbiol Rev 57, 522-542.

McElhaney, R. N. (1982). Effects of membrane lipids on transport and enzymic activities. Curr Top Membr Transp 17, 317-380.

McMeekin, T. A., Chandler, R. E., Doe, P. E., Garland, C. D., Olley, J., Putro, S. \& Ratkowsky, D. A. (1987). Model for combined effect of temperature and salt concentration/water activity on the growth rate of Staphylococcus xylosus. J Appl Bacteriol 62, 543-550.

McMeekin, T. A., Olley, J. N., Ross, T. \& Ratkowsky, D. A. (1993). Predictive Microbiology: Theory and Application. Taunton: Research Studies Press.

Nichols, D. S., Nichols, P. D. \& McMeekin, T. A. (1995). A new n$\mathrm{C}_{31: 9}$ hydrocarbon from Antarctic bacteria. FEMS Microbiol Lett 125, 281-286.

Ratkowsky, D. A., Olley, J., McMeekin, T. A. \& Ball, A. (1982). Relationship between temperature and growth rate of bacterial cultures. J Bacteriol 149, 1-5.

Ratkowsky, D. A., Lowry, R. K., McMeekin, T. A., Stokes, A. N. \& Chandler, R. E. (1983). Model for bacterial culture growth rate throughout the entire biokinetic temperature range. J Bacterio/ 154 , $1222-1226$.

Rilfors, L., Lindblom, G., Wieslånder, A. \& Christiansson, A. (1984). Lipid bilayer stability in biological membranes. In Biomembranes, vol. 12, pp. 203-246. Edited by M. Kates \& L. A. Manson. New York: Plenum.

Russell, N. J. (1984a). Mechanisms of thermal adaptation in bacteria: blueprints for survival. Trends Biocbem Sci 9, 108-112.

Russell, N. J. (1984b). The regulation of membrane fluidity in bacteria by acyl chain length changes. In Membrane Fluidity, pp. 329-347. Edited by M. Kates \& L. A. Manson. New York: Plenum.

Sinensky, M. (1974). Homeoviscous adaptation - a homeostatic process that regulates the viscosity of membrane lipids in $E$. coli. Proc Natl Acad Sci US A 71, 522-525.

White, D. C., Davis, W. M., Nickels, J. S., King, J. D. \& Bobbie, R. J. (1979). Determination of the sedimentary microbial biomass by extractible lipid phosphate. Oecologia 40, 51-62.

White, R. H. (1984). The biosynthesis of $\mathrm{n}-\left[{ }^{2} \mathrm{H}_{7}\right]$ fatty acids by Artbrobacter globiformis from $\left[\mathrm{U}_{-}{ }^{2} \mathrm{H}_{15}\right]$ octanoic acid. Lipids 19, $570-572$.

Wieslånder, A., Nordström, S., Dhalquist, A., Rilfors, L. \& Lindblom, G. (1995). Membrane lipid composition and cell size of Acholeplasma laidlawii strain A are strongly influenced by lipid acyl chain length. Eur J Biochem 227, 734-744.

Zobell, C. E. (1946). Marine Microbiology. Waltham, Chronica Botanica.

Received 24 July 1995; revised 21 November 1995; accepted 27 November 1995. 